\title{
Lifetime and performance alteration of photovoltaic panels, the case of Aerzen, Germany
}

\section{Furkan DİNÇER}

Kahramanmaras Sutcu Imam University, Department of Electrical-Electronics Engineering, furkandincer@ksu.edu.tr, Orcid No: 0000-0001-6787-0850

\begin{tabular}{|c|c|}
\hline ARTICLE INFO & ABSTRACT \\
\hline Article history: & \\
\hline $\begin{array}{l}\text { Received } 25 \text { July } 2021 \\
\text { Received in revised form } 18 \\
\text { September } 2021 \\
\text { Accepted } 18 \text { September } 2021 \\
\text { Available online } 28 \text { September } 2021\end{array}$ & $\begin{array}{l}\text { Solar energy is unlimited, flawlessly, sustainable and among of the most preferred renewable energy } \\
\text { source. The rapid development and the increasing demand in solar energy technologies provided an } \\
\text { increasing the production and played an important role for reducing costs. Thousands of manufacturers } \\
\text { around the world produce solar panels however solar panels are also exposed to aging during their } \\
\text { lifetime. This aging of the solar panel is generally expressed by the manufacturers as } 10 \% \text { generation }\end{array}$ \\
\hline $\begin{array}{l}\text { Keywords: } \\
\text { Solar panel, lifetime, performance, } \\
\text { Aerzen, PVGIS }\end{array}$ & $\begin{array}{l}\text { performance loss in } 10 \text { years and } 20 \% \text { in } 25 \text { years. However, solar panel technology is not a very old } \\
\text { technology and these statements on aging are in need of confirmation. So, in this study, the data of a } \\
\text { solar power plant that has been operating for about } 13 \text { years has been examined in detail and the same } \\
\text { plant has been modeled with numerical programme for the case of Aerzen, Germany. Panel aging was } \\
\text { discussed by comparing the simulation data with the experimental data. }\end{array}$ \\
\hline
\end{tabular}

Doi: 10.24012/dumf.1001925

* Corresponding author

\section{Introduction}

With the development of technology, global electricity energy demand is growing [1-3]. Digitized world gives more importance to electrical energy, storage of generated energy and sustainable energy technologies. Among of the sustainable and environmentally friendly renewable energy sources, the most preferred problem-free, unlimited and modular source is solar energy. The desired amount of electrical energy can be generated from solar energy by means of solar photovoltaic panels. Since solar panels are modular, solar panels can be combined modularly as much as the amount of electrical energy needed and the desired power level can be easily reached. Modularity is one of the most important advantages of solar energy source

As in developed countries in the world, there is an intense interest in electricity energy generation from solar energy in developing countries. Industrialists desire to invest in the solar energy sector. In this context, the installed electricity energy generation power plants that generate electricity from solar energy capacity is approximately 7 GW in Turkey [4]. However, considering the solar radiation value of Turkey, the duration of sunshine and the advantages of being under the sun zone, installed power is at much lower levels in Turkey. Germany, have lower potential although it has installed solar power up to 50 GW.

The cost of electricity generation from solar energy has been decreasing rapidly in the last two decades. The rapid development in solar energy technologies and the increasing demand in the world provided an increase in production and played an important role in reducing costs. With the increasing production, thousands of solar panel manufacturers operate in the world. There are many solar panel manufacturers in the world. Panel manufacturers around the world offer an average of ten years of physical warranty for panels and a twenty-five year warranty for generation performance as standard. Generally, this generation performance is promised as $90 \%$ at the end of the tenth year and $80 \%$ at the end of the twenty-fifth year following the production of the panel. This is due to the aging of the solar panel over the years. Solar panels are exposed to aging over the years following production, and accordingly, electrical energy generation begins to decline. There are many studies on photovoltaic plants. These papers examine potential and efficiencies of photovoltaic plants. One of them is [5] in order to evaluate potential of Sanliurfa, the annual energy generation values of rooftop photovoltaic panels were calculated by authors. Three different photovoltaic panel technologies are evaluated for 
the calculations. Other one [6] is related with utilization of a sun-tracking parabolic dish collector for water heating application under the climatic conditions of Diyarbakır. These and other similar studies have addressed the capacities and performances of photovoltaic power plants.

In this study, panel aging situation of the grid connected roof mounted solar power plant is discussed and examined as detailed. The plant is a $25,74 \mathrm{kWp}$ grid-connected rooftop solar power plant, and 156 units of $165 \mathrm{~W} \mathrm{BP}$ solar brand BP 3165 model photovoltaic panels and 3 units of $8 \mathrm{~kW}$ SMA brand Sunny Mini Central 8000TL model inverters are used. No revision has been made in the plant so far. It was installed in year of 2008 and has been in operation for about 13 years. This solar power plant is located in the city of Aerzen, Lower Saxony state of Germany. It was also simulated and modeled in order to compare the analyses. The modeled solar power plant generation data and the experimentally produced data were compared as detailed. Model success was also analyzed.

\section{Selected Location Information of Solar Power Plant}

Aerzen is a municipality in the German state of Lower Saxony. Its population is 10,556 as of December 31, 2017. Area; It is $105.06 \mathrm{~km}^{2}$ and its altitude value is $173 \mathrm{~m} \mathrm{[7].}$ The image of the selected location is presented in Figure 1.

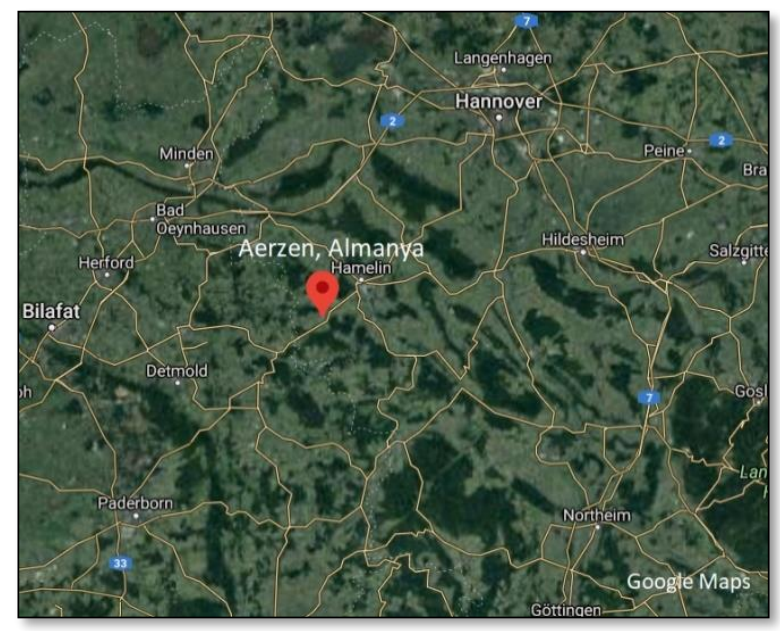

Figure 1. Image of the selected location for the certain solar power plant [8]

The photovoltaic power potential atlas of Germany is shown in Figure 2. As can be seen from the figure, the regions with the highest solar energy potential are around Munich and Stuttgart. The potential here is approximately $1.200 \mathrm{kWh} / \mathrm{kWp}$. The chosen location has a potential of approximately $1.020 \mathrm{kWh} / \mathrm{kWp}$.

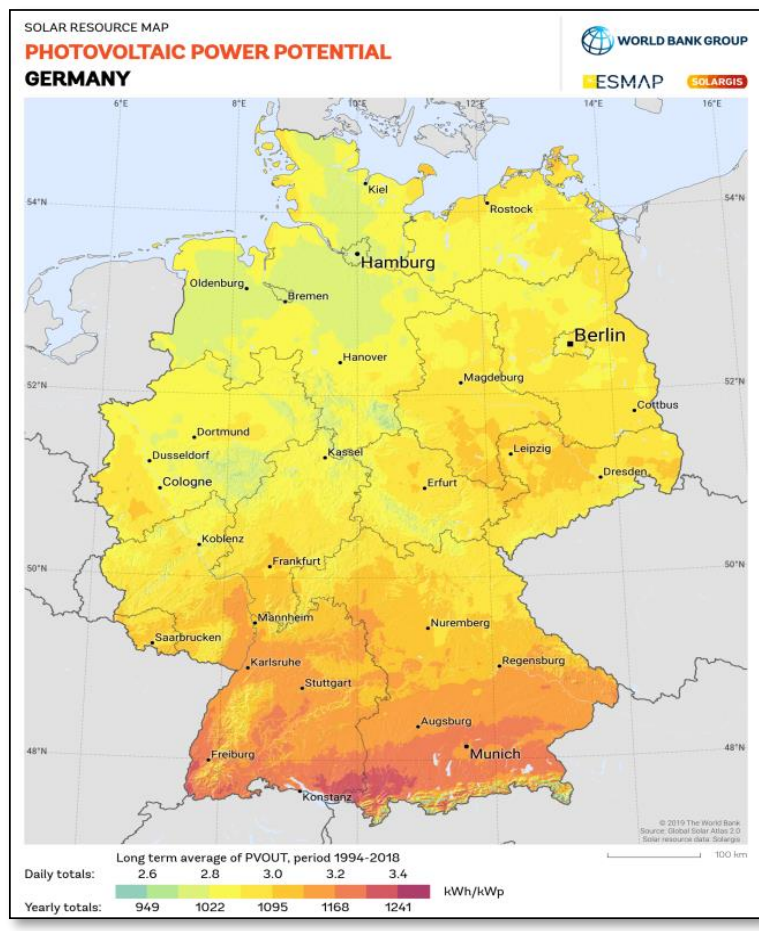

Figure 2. Photovoltaic power potential atlas of Germany

\section{Simulation Analysis and Results for Selected Solar Power Plant}

With the photovoltaic geographical information system organized by the European Union, the solar power plant in the city of Aerzen, Lower Saxony, Germany, was modeled in its current state [10]. The input and output information of the modeling are presented in Table 1 . In the same way as the installed power plant, the photovoltaic installed power was chosen as $25.74 \mathrm{kWp}$ in the modeling. Crystal silicon was chosen as the panel type and simulation data was loaded as a fixed system. Effective losses such as system losses and environmental factors were entered into the simulation as $19.67 \%$. According to the obtained results, it is expected to generate $24.468,45 \mathrm{kWh}$ of electrical energy annually. In addition, the estimated radiation values related to the location are presented in Table 1 


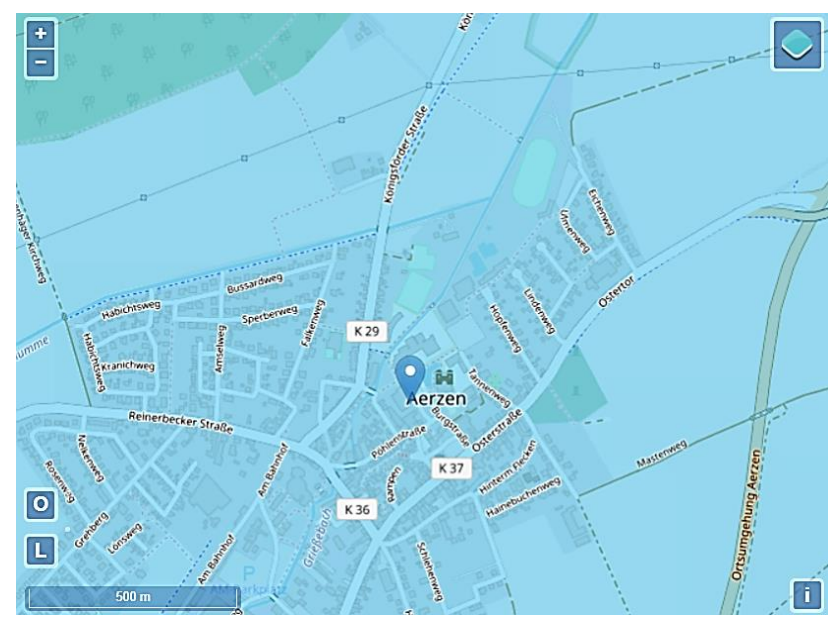

Figure 3. Selected location for PVGIS simulation

Table 1. Simulation data of modeling

\begin{tabular}{|lc|}
\hline Simulation Data: & \\
\hline Location [Latitude/Longitude]: & $52.049,9.263$ \\
\hline Horizon: & Calculated \\
\hline Data System Used: & $\begin{array}{c}\text { PVGIS- } \\
\text { SARAH }\end{array}$ \\
\hline Panel Technology: & $\begin{array}{c}\text { Crystal } \\
\text { Silicon }\end{array}$ \\
\hline Installed Power [kWp]: & 25,74 \\
\hline System Loss [\%]: & 14 \\
\hline Simulation Outputs: & 35 \\
\hline Tilt Angle: & 0 \\
\hline Azimuth Angle: & $24.468,45$ \\
\hline Annual PV Energy Production [kWh]: & $1.183,32$ \\
\hline Annual Planar Radiation [kWh/m2]: & $1.257,98$ \\
\hline Year-to-Year Variability [kWh]: & $-19,67$ \\
\hline Other Losses: & $-3,1$ \\
\hline Reflection Losses [\%]: & 1,85 \\
\hline Spectral Effects [\%]: & $-5,35$ \\
\hline $\begin{array}{l}\text { Temperature and Environmental } \\
\text { Losses [\%]: }\end{array}$ & \\
\hline Total Loss [\%]: & \\
\hline & \\
\hline
\end{tabular}

As a result of the simulation values entry given in Table 1, the variation of the production distribution by months is presented in detail in Figure 4. According to the production estimation, the highest generation on a yearly basis is July with $3,156 \mathrm{kWh}$, while the lowest generation is December with a production value of $577 \mathrm{kWh}$. Especially in months of May, June, July and August, the production values remained at a good level with the long sunshine periods. Total annual production estimate of $24.468,45 \mathrm{kWh}$ was obtained as a result of simulation.

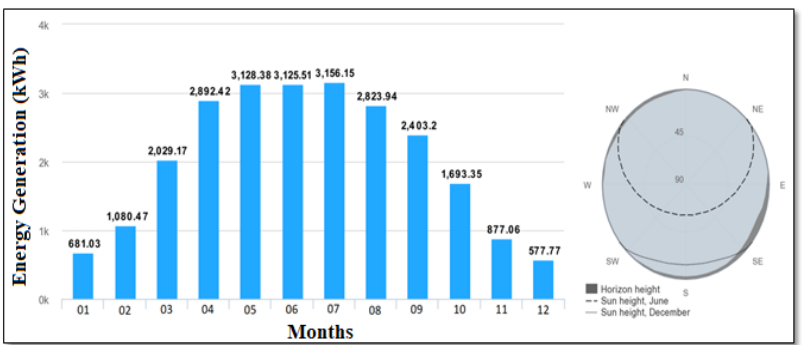

Figure 4. Electrical energy generation according to the monthly distribution as a result of the simulation

\section{Experimental Analysis and Results for Selected Solar Power Plant}

Experimental data of the solar power plant located in the city of Aerzen, Lower Saxony state of Germany, are presented in detail in this section. This solar power plant is installed on 07.04.2008. It is a power plant that has been in operation for about 13 years. BP Solar BP 3165 type solar panels are used in the power plant. The electrical properties and physical parameters of panel Isc, Voc, FF etc. are presented in Table 2. Experimental data of the power plant were obtained from Sunny Portal as open access. In Figure 5, the production distribution of the experimentally existing power plant by months is given in detail [11]. 156 pieces of $165 \mathrm{~W}$ solar panels are used in the power plant and its total installed power is 25,740 kWp. 3 Sunny Mini Central 8000TL type solar inverters are used. AC power is $24 \mathrm{kWe}$.

Table 2. Electrical characteristics of BP Solar BP 3165 type solar panel

\begin{tabular}{lc}
\hline Panel Power (Pmax) & $165 \mathrm{~W}$ \\
\hline Voltage Value (Vmp) & $35,2 \mathrm{~V}$ \\
\hline Current Value (Imp) & $4,7 \mathrm{~A}$ \\
Short Circuit Current (Isc) & $5,1 \mathrm{~A}$ \\
\hline Open Circuit Voltage (Voc) & $44,2 \mathrm{~V}$ \\
Temperature Coefficient (Isc) & $(0.065 \pm 0.015) \% /{ }^{\circ} \mathrm{C}$ \\
\hline Temperature Coefficient (Voc) & $-(160 \pm 20) \mathrm{mV} /{ }^{\circ} \mathrm{C}$ \\
\hline Temperature Coefficient (Pmax) & $-(0.5 \pm 0.05) \% /{ }^{\circ} \mathrm{C}$ \\
\hline
\end{tabular}

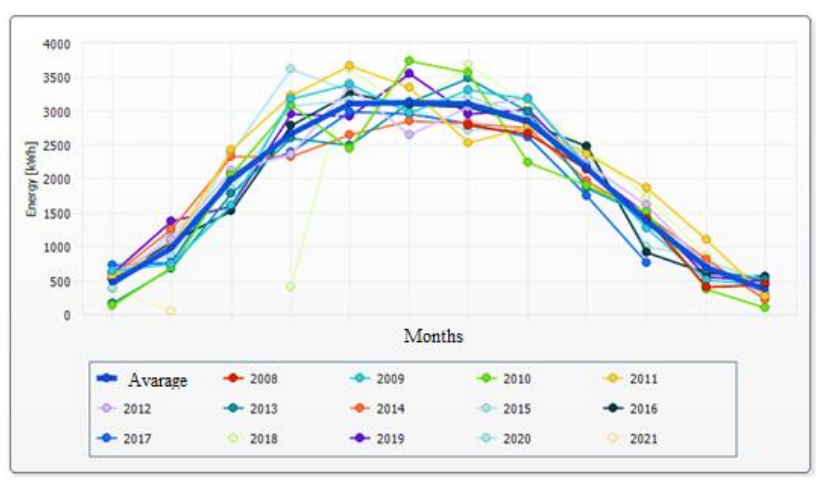

Figure 5. Distribution of electrical energy production of experimentally existing power plant by months 
Experimentally, the electrical energy generation distribution of the existing power plant by years is shown in Figure 6. There is a lack of data for 6-7 months in 2008, 2 months in 2017 and 3 months in 2018, and based on the years when the data is not missing, it is seen that the annual production average is generally $22.000 \mathrm{kWh}-$ $23.000 \mathrm{kWh}$. While $23.527 \mathrm{kWh}$ of electrical energy was produced in $2009,25.192 \mathrm{kWh}$ of electricity was produced in $2011,23.843 \mathrm{kWh}$ in 2015, $23.723 \mathrm{kWh}$ in 2019 and $23.820 \mathrm{kWh}$ in 2020.

The variation in annual climate data remains limited to $5 \%$. The effect of climate change over the years on aging can be distinguished. In an unimproved power plant, the generation data is sufficient for the assessment of aging. The most important indicator of aging is loss of production. No change is foreseen for the physical parameters of the panel.

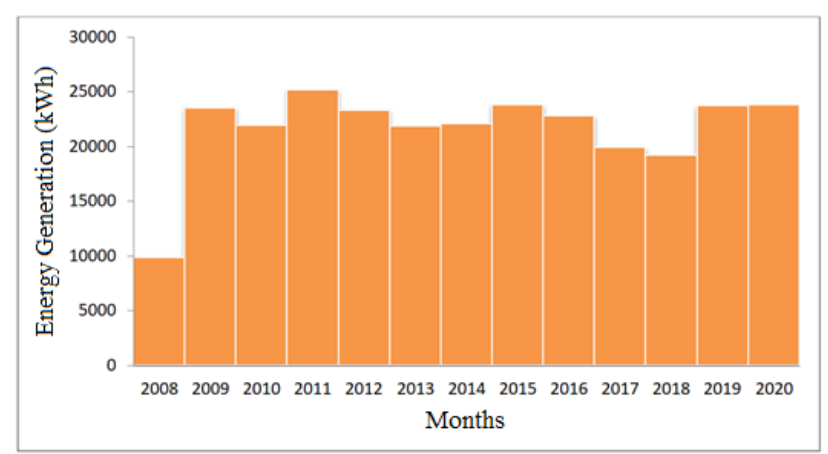

Figure 6. Electrical Energy Generation Distribution of Experimentally Existing Power Plant by Years

\section{Discussion and Conclusion}

In this study, a solar power plant that has been in operation for approximately 13 years within the boundaries of a municipality in Aerzen, Lower Saxony, Germany, is analyzed in detail. At the same time, this plant is modeled numerically at the specified location and features. The modeling results and the existing power plant data in production overlap very well. This situation shows that the model is successful in implementation.

The aging of the panels is related to the temperature to which they are exposed. For the location where the study was carried out as experimental and simulation; the average annual maximum temperature is: $14.0^{\circ}$ Celsius (57.2 $2^{\circ}$ Fahrenheit). The average annual minimum temperature is: $6.0^{\circ}$ Celsius $\left(42.8^{\circ}\right.$ Fahrenheit) [12]. The aging of the panels was slow as the annual average Temperature was low. Measured production values show that aging is low. It is known that panel aging occurs as long as the solar panels are in operation after their production. In the technical specifications of the panel, whose electrical data are presented in Table 2 and used in the facility, a minimum of $90 \%$ electrical energy performance is guaranteed at the end of 10 years and $80 \%$ at the end of 25 years. It has been clearly observed that the production of these panels, which have completed about 13 years, is in a better position than guaranteed.

According to the results obtained; although it is a solar power plant that has been in operation for about 13 years, the aging effect of the panels has not been observed clearly. The amount of electrical energy produced in 2009 and the amount of electrical energy produced in 2020 are very close to each other. Although there are significant differences in electricity generation on a monthly basis, annual production values are approximately close to each other. Although there are many scientific studies on panel aging, long-term measurement-based data are not available in the scientific literature. 13 years of actual measurement data is important for photovoltaic solar energy systems.

As a result; while there may be differences in the panel brands, the expected rapid aging did not occur in this panel used. Although the panels have been in operation for approximately 13 years, a very low level of panel aging has occurred.

\section{References}

[1]. F. Dincer, S. Rustemli, S. Yilmaz, A. Cingi, Kilis ili için farklı yüksekliklerdeki rüzgâr potansiyelinin belirlenmesi, Bitlis Eren Üniversitesi Fen Bilimleri Dergisi, vol. 6, no. 1, pp. 12 - 20, 2017.

[2]. M. Akdag, S. Rustemli, Transmission line fault location: Simulation of real faults using wavelet transform based travelling wave methods, Bitlis Eren University Journal of Science and Technology, vol. 9, no. 2, pp. 88 - 98, 2019.

[3]. S. Rustemli, I. Demir, Analysis and simulation of single phaseto-ground short circuit fault in Van $154 \mathrm{kV}$ substation: An experimental assessment, Bitlis Eren University Journal of Science and Technology, vol. 9 , no. 2, pp. 76-82, 2019

[4]. Lisanssız Elektrik Kurulu Gücünün Kaynaklara Göre Dağılımı, https://www.epdk.gov.tr/Detay/Icerik/5-9378/2021-yili-ocak-ayisektor-raporlari-yayinlanmisti date of access: 10 April 2021.

[5]. E. Yıldırım, M. A. Aktacir, Çatı Üstü PV Elektrik Üretim Potansiyelinin Belirlenmesi: Şanlıurfa Örneği, Dicle University Journal of Engineering, vol. 12, no. 1, doi: 10.24012/dumf.860242.

[6]. A. G. Devecioğlu, M. Hatipoğlu. V. Oruç, Utilization of a suntracking parabolic dish collector for water heating application, Dicle University Journal of Engineering, vol. 12, no. 2, doi: 10.24012/dumf.784088.

[7]. Aerzen, Germany, wikipedia.org, date of access: 10 April 2021.

[8]. Google Maps, www.google.com/maps/?hl=tr, date of access: 10 April 2021.

[9]. Solar PV Map, https://solargis.com/maps-and-gisdata/download/germany, date of access: 03 April 2021.

[10]. Solar PV Tool, https://re.jrc.ec.europa.eu/pvg_tools/en/\#PVP, date of access: 03 April 2021.

[11]. Solar PV Inverter, www.sunnyportal.com, date of access: 16 February 2021.

[12]. https://weather-and-climate.com/average-monthly-min-maxTemperature,aerzen-lower-saxony-de,Germany, date of access: 03 August 2021 